\title{
Produksi Simplisia dan Kandungan Bioaktif Daun Tempuyung (Sonchus arvensis L.) pada Berbagai Dosis Pupuk Kandang Kambing
}

\author{
Production of Biomass and Bioactive Compound of Perennial Sowthistle (Sonchus $\underline{\text { arvensis }}$ \\ L.) - Leaf at Different Goat Manure Rates \\ Yulisda Eka Wardani ${ }^{1}$ dan Maya Melati ${ }^{1^{*}}$ \\ Diterima 10 Juni 2014/Disetujui 13 Oktober 2014
}

\begin{abstract}
Perennial sowthistle (Sonchus arvensis $\mathrm{L}$.) is utilized as herbal medicine, because it contains potassium, silica, sodium, flavonoids, taraxasterol, inositol and phenolic acids. Organic cultivation for medicinal plant is preferable, but the technique has not been well developed. Therefore, the study was aimed at examining the effect of goat manure rates on simplicia production to generate recommended rate of goat manure. The experiment was conducted in organic experimental field of IPB at Cikarawang Bogor, November 2013 - March 2014. The experiment used a randomized completely block design with a factor consisted of five rates of manure, i.e 0, 5, 10, 15 and 20 tons $\mathrm{ha}^{-1}$ with three replications. The results showed that sheep manure did not significanly affect all variables tested. There was no optimum rate of goat manure to recommend. The maximum production of simplicia was reached at 8 MST with the average amount of $120 \mathrm{~kg}$ dry leaves $\mathrm{ha}^{-1}$.
\end{abstract}

Key words: Perennial sowthistle, biomass, bioactive, compound, organic fertilizer

\begin{abstract}
ABSTRAK
Tempuyung (Sonchus arvensis L.) dimanfaatkan sebagai obat herbal, karena memiliki kandungan kalium, silika, natrium, flavonoid, taraksasterol, inositol dan asam fenolat. Teknik budi daya tempuyung secara organik masih terbatas, namun membudidayakan tanaman obat secara organik lebih diharapkan. Penelitian ini bertujuan untuk menguji pengaruh pupuk kandang kambing dengan berbagai dosis terhadap produksi simplisia daun tempuyung serta menghasikan rekomendasi dosis pupuk kandang kambing yang tepat untuk budi daya tempuyung. Percobaan dilaksanakan di Kebun Percobaan Organik IPB, Cikarawang, Bogor, pada bulan November 2013 - Maret 2014. Percobaan menggunakan rancangan kelompok lengkap teracak dengan satu faktor, yaitu lima dosis pupuk kandang, terdiri atas $0,5,10,15$ dan 20 ton ha $^{-1}$; setiap perlakuan memiliki tiga ulangan. Hasil penelitian menunjukan bahwa pemberian pupuk kandang kambing dengan berbagai dosis tidak mempengaruhi secara signifikan seluruh peubah, walaupun pemberian pupuk kandang kambing menyebabkan pertumbuhan tanaman yang baik. Selain itu, produktivitas maksimal simplisia daun tempuyung terdapat pada 8 MST dengan rata-rata mencapai $120 \mathrm{~kg} \mathrm{ha}^{-1}$.
\end{abstract}

Kata kunci: flavonoid, organik, tanaman obat

\section{PENDAHULUAN}

Masyarakat Indonesia sudah lama memiliki budaya mengkonsumsi obat-obatan tradisional, karena efek samping dari obat tradisional lebih rendah daripada obat kimia.
Selain itu, tanaman obat juga memiliki potensi sebagai sumber pangan fungsional yang berfungsi sebagai pencegahan terhadap penyakit (Winarti dan Nurdjanah, 2005). Indonesia memiliki berbagai jenis komoditas tanaman obat baik yang sudah dibudidayakan,

\footnotetext{
${ }^{1}$ Departemen Agronomi dan Hortikultura, Fakultas Pertanian, Institut Pertanian Bogor (Bogor Agricultural University), J1. Meranti, Kampus IPB Darmaga, Bogor 16680, Indonesia

Telp.\&Faks.62-251-8629353 e-mail: maya_melati05@yahoo.com (*penulis korespondensi)
} 
maupun masih tumbuh secara liar. Berdasarkan Keputsan Menteri Pertanian Republik Indonesia nomor: 511/Kpts/PD.310/9/2006, bahwa ada 66 jenis tanaman obat yang telah dikembangkan Indonesia serta berada dalam tanaman binaan Direktorat Jenderal Hortikultura dan salah satu dari tanaman tersebut adalah tempuyung (Sonchus arvensis L) (Direktorat Jenderal Hortikultura, 2012) yang berkhasiat sebagai pemecah batu ginjal (Hidayati et al., 2009).

Tanaman tempuyung termasuk famili Asteraceae dan spesies Sonchus arvensis L. Tempuyung memiliki ciri fisik yang khas, yaitu daun tunggal yang berbentuk lanset atau lonjong dengan panjang 6-48 $\mathrm{cm}$ dan lebar 3$12 \mathrm{~cm}$ (Sulasna et al., 2004), tepi daun menyirip tidak beraturan dan berwarna hijau muda. Bunga berbentuk bonggol yang tergabung dalam malai, bertangkai, mahkota berbentuk jarum dengan warna kuning cerah. Buah tempuyung berbentuk kotak dan berusuk lima, berwarna kuning dengan panjang hingga $4 \mathrm{~mm}$. Tempuyung juga memiliki rhizoma berdiameter $0.25-0.5 \mathrm{~cm}$, berasal dari akar utama dan bercabang-cabang kecil, kedalaman tanah yang dapat ditembus perakaran tempuyung mencapai 2-5 inch $(5-12 \mathrm{~cm})$, tapi tunas vegetatif dapat mencapai kedalaman 20 inch $(50 \mathrm{~cm})$ di bawah permukaan tanah dan akar vertikal dapat menembus kedalaman tanah hingga $2 \mathrm{~m}$ (Dalimartha, 2005). Kandungan kimia yang terdapat pada daun tempuyung, yaitu berupa ion-ion mineral, seperti $\mathrm{Si}, \mathrm{K}, \mathrm{Mg}, \mathrm{Na}$, dan senyawa organik flavonoid (kaempferol, luteolin-7-O-glukosida, apigenin-7-O-glukosida) (Rohaeti et al., 2011), kumarin (skepoletin), taraksasterol, inositol dan asam fenolat (sinamat, kumarat, vanilat) (Yuliarti, 2013).

Simplisia daun tempuyung (Sonchus arvensis L.) sering digunakan sebagai obat, sehingga perlu adanya teknik budidaya secara organik untuk meningkatkan kualitas simplisia daun tempuyung, serta mengurangi pencemaran bahan kimia sintetik yang berasal dari penggunaan pupuk dan pestisida anorganik (Direktorat Budidaya dan Pascapanen Sayuran dan Tanaman Obat, 2009). Salah satu input yang digunakan dalam budidaya tanaman secara organik adalah pupuk kandang. Hasil penelitian Gatari dan Melati (2014) menunjukkan terdapat kecenderungan pertumbuhan tanaman tempuyung yang lebih baik dengan nenambahkan pupuk kandang sapi dan arang sekam. Baskoro (2011) melaporkan penambahan bahan organik media tanam menghasilkan pertumbuhan bibit binahong yang lebih baik dibandingkan tanpa penambahan pupuk organik. Pupuk kandang kambing merupakan salah satu pupuk organik yang memiliki kandungan unsur $\mathrm{N}$ dan $\mathrm{K}$ lebih besar dari pupuk kandang sapi (Hardjowigeno, 1989).

Dosis pupuk kandang kambing yang optimal perlu diperhatikan karena akan mempengaruhi produksi simplisia daun tempuyung. Menurut Izhar dan Susila (2010) rekomendasi pemupukan yang optimal dapat diperoleh melalui optimasi faktor-faktor yang akan berpengaruh, seperti tujuan pemupukan, jenis tanah, dan kadar hara tersedia dalam tanah. Informasi mengenai pemanfaatan pupuk kandang kambing untuk budi daya tempuyung secara organik masih terbatas. Oleh karena itu perlu dipelajari peranan pupuk kandang kambing untuk pertumbuhan tanaman dan penentuan dosis pupuk yang tepat.

Penelitian ini bertujuan untuk menguji pengaruh penggunaan pupuk kandang kambing dengan berbagai dosis terhadap produksi dan kandungan bioaktif simplisia daun tempuyung (Sonchus arvensis L.) serta menghasilkan rekomendasi dosis pupuk kandang kambing yang paling optimal dalam budidaya tempuyung (Sonchus arvensis L.).

\section{BAHAN DAN METODE}

Percobaan dilaksanakan di Kebun Percobaan Organik di Cikarawang, Darmaga, Bogor dengan ketinggian $\pm 250 \mathrm{~m}$ dpl. Pengamatan pasca panen di Laboratorium Pasca Panen, Departemen Agronomi dan Hortikultura, Fakultas Pertanian, IPB serta pengamatan bioaktif di Laboratorium Pengujian, Departemen Agronomi dan Hortikultura. Percobaan ini dilaksanakan dari bulan November 2013 hingga Maret 2014.

Bahan tanam yang digunakan untuk percobaan ini adalah bibit tempuyung yang berumur \pm 4 minggu hasil dari stek anakan. Bahan tanam diperoleh dari kebun Biofarmaka, Institut Pertanian Bogor. Bahan lainnya yang digunakan adalah pupuk kandang kambing, arang sekam, kapur dan amplop coklat. Peralatan yang digunakan adalah alat 
budi daya pertanian, meteran, timbangan analitik, oven $60{ }^{\circ} \mathrm{C}$, alat tulis dan gunting.

Penelitian ini menggunakan model rancangan kelompok lengkap teracak (RKLT) dengan faktor perlakuan, yaitu dosis pupuk kandang, yang terdiri dari lima taraf, yaitu 0 , 5, 10, 15 dan 20 ton ha $^{-1}$ dengan tiga ulangan, sehingga terdapat 15 satuan percobaan. Masingmasing satuan percobaan terdiri atas 36 tanaman.

Petakan percobaan yang berukuran 1.2 m x 2.7 m diberi pupuk kandang kambing dengan dosis yang telah ditentukan. Pupuk kandang diaplikasikan dengan cara disebar pada bedengan sebulan sebelum transplanting. Petak percobaan juga diberi kapur dan arang sekam padi dengan dosis 1 ton ha $^{-1}$ pada 7 hari sebelum transplanting dengan cara ditebar pada permukaan tanah. Menurut Burhanudin dan Nurmansyah (2010), pemberian kapur dimaksudkan untuk meningkatkan $\mathrm{pH}$ tanah dan dapat memberikan kondisi yang baik bagi aktivitas mikroba tanah. Pembibitan tempuyung dilakukan selama satu bulan setelah distek dengan naungan $40 \%$. Bibit tempuyung ditanam ke lahan setelah berumur empat minggu dengan jarak tanam $30 \mathrm{~cm} \mathrm{x} 30 \mathrm{~cm}$ mengacu pada Nurhayati et al. (2013).

Pemeliharaan yang dilakukan, yaitu penyulaman pada $1 \mathrm{MST}$, penyiraman dan penyiangan gulma (dengan cara mencabut gulma) hingga 9 MST, serta pemangkasan bunga pada 6 MST. Pemangkasan bunga dilakukan dengan cara menggunting batang yang berbunga pada buku ke tiga di bawah pangkal bunga, hal ini bertujuan untuk memacu pertumbuhan vegetatif tanaman.

Tanaman dipanen secara destruktif (dengan mengambil seluruh bagian tanaman) pada umur 4, 6 dan 8 MST, dan panen dengan cara memotong pangkal batang pada 9 MST. Setelah dipanen tanaman dicuci dan dikeringanginkan selama beberapa menit, kemudian bagian daun, batang, bunga dan akar dipisahkan dan ditimbang untuk memperoleh data bobot segar tanaman. Selanjutnya bagian tanaman tersebut dijemur di bawah sinar matahari selama 1-2 hari (tergantung kondisi cuaca) untuk mempercepat pengeringan dalam oven. Setiap bagian tanaman dikeringkan dalam oven dengan suhu $60{ }^{0} \mathrm{C}$ agar kandungan bioaktif dalam daun terjaga. Setelah 2 hari pengeringan dalam oven, bobot kering tanaman ditimbang.

Peubah vegetatif yang diamati setiap minggu adalah tinggi tanaman, jumlah daun (dihitung pada daun yang sudah membuka secara penuh), panjang dan lebar daun terpanjang serta diameter tajuk. Saat tanaman berumur 4, 6 dan 8 MST dilakukan pengamatan biomassa tanaman melalui penimbangan bobot basah dan bobot kering daun, batang, bunga dan akar dengan mengambil 2 tanaman dalam setiap petak percobaan. Sampel tanaman pada 9 MST dilakukan hal yang sama untuk perlakuan tanpa pengukuran biomassa akar, karena akar tidak dipanen.

Analisis pasca panen yang dilakukan, yaitu analisis kandungan klorofil, antosianin dan karoten menggunakan metode Sims and Gamon (2002) pada daun muda percabangan dan daun tua ketika 6 dan 8 MST. Dilakukan pula analisis kandungan flavonoid menggunakan metode $\mathrm{AlCl}_{3}$ dan analisis kandungan NPK pada daun ketika tanaman berumur 8 MST.

Data pengamatan yang diperoleh, dianalisis menggunakan uji $\mathrm{F}$ pada $\alpha=5 \%$. Apabila terdapat pengaruh yang signifikan dari perlakuan terhadap peubah yang diamati, maka setiap taraf perlakuan dibandingkan dengan menggunakan uji lanjut DMRT (Duncan's Multiple Range Test) pada taraf kesalahan 5\%, analisis regresi dan korelasi.

\section{HASIL DAN PEMBAHASAN}

\section{Kondisi Umum}

Rata-rata suhu bulanan selama percobaan dilaksanakan adalah $25.1{ }^{0} \mathrm{C}$ dengan kisaran $23.2{ }^{0} \mathrm{C}$ hingga $28.2{ }^{0} \mathrm{C}$, sedangkan rata-rata curah hujan bulanan selama percobaan, yaitu $440 \mathrm{~mm}$ dengan kisaran $281 \mathrm{~mm}$ hingga 702 mm. Rata-rata kelembaban bulanan adalah $88 \%$ dengan kisaran 86-89\% (BMKG, 2014). Sebelum percobaan dilaksanakan, contoh tanah diambil secara komposit untuk dilakukan analisis kandungan hara tanah. Kondisi tanah pada lokasi percobaan memiliki $\mathrm{pH}$ sebesar 6.40, sedangkan kandungan N-total sebesar $0.12 \%$, P-Bray I sebesar 8.0 ppm dan kadar kalium sebesar $1.15 \mathrm{me} / 100 \mathrm{~g}$. Hal ini menunjukan kondisi lahan percobaan yang agak asam dan memiliki kandungan nitrogen rendah, fosfor sedang dan kalium yang sangat tinggi.

Hama dan penyakit yang menyerang tempuyung selama percobaan berlangsung adalah ulat, belalang, kutu daun (Aphid sp.) dan cendawan Puccinia sp. Kutu daun 
menyerang pangkal daun bagian bawah dan sekitar titik tumbuh mulai 3 MST, sedangkan ulat dan belalang menyerang daun. Curah hujan bulanan pada umur tanaman 1 hingga 3 MST mencapai $702 \mathrm{~mm}$, tingginya curah hujan dan kelembaban menyebabkan 30\% tanaman tempuyung terserang cendawan Puccinia sp. dengan gejala ringan berupa bintik kuning pada daun tua yang dekat tanah. Bahkan pada 8 MST persentase daun yang rusak mencapai 93.14\%. Menurut Wahyuno (2012) karat daun yang disebabkan oleh Puccinia sp. memiliki gejala bercak coklat kehitaman dengan warna kuning di bagian tepi dan tersebar secara acak.

Tanaman tempuyung mulai berbunga pada 5 MST, akan tetapi nilai dari peubah vegetatif terus bertambah hingga 8 MST. Secara umum dalam penelitian ini, tanaman tempuyung memiliki keragaan yang baik. Pemangkasan bunga pada percobaan ini, yang dilakukan saat tanaman berumur 6 MST justru meningkatkan jumlah cabang dan bunga, sehingga pada budidaya sebaiknya tidak perlu melakukan pemangkasan. Padahal menurut Wahyuningsih (2005) pemangkasan tangkai bunga pada awal pembungaan dapat meningkatkan jumlah daun tempuyung karena merangsang pertumbuhan tunas lateral.

Kesulitan penyediaan bahan tanam menyebabkan adanya keragaman yang agak tinggi, diduga juga mempengaruhi signifikasi data meskipun data sudah ditransformasi. Bibit yang digunakan mempunyai ukuran yang beragam, sehingga mempunyai kecepatan tumbuh yang berbeda. Selain itu, pemberian pupuk kandang kambing dengan berbagai dosis dalam percobaan ini tidak menunjukan pengaruh yang nyata terhadap seluruh peubah yang diamati.

\section{Pengaruh Dosis Pupuk Kandang Kambing terhadap Peubah Vegetatif}

Ketika tanaman tempuyung memasuki fase generatif (5 MST) tanaman cepat tumbuh tinggi, hal ini dapat dilihat dari selisih tinggi tanaman pada 5 dan 6 MST yang berkisar antara 6.37 hingga 13.28. Secara statistik, tidak ada pengaruh dosis pupuk terhadap tinggi tanaman meskipun pada 3-6 MST nilai tinggi tanaman dengan aplikasi 15 ton $\mathrm{ha}^{-1}$ lebih tinggi daripada perlakuan lainnya (Tabel 1).

Tidak ada perbedaan nyata jumlah daun akibat perbedaan dosis pupuk, meskipun pada 7-8 MST ada selisih yang lebih besar antara jumlah daun dengan aplikasi pupuk kandang 20 ton ha ${ }^{-1}$ dan tanpa pupuk (Tabel 2).

Peubah panjang dan lebar daun serta diameter tajuk juga tidak berbeda antar dosis pupuk (Tabel 3). Nilai peubah panjang dan lebar daun yang fluktuatif disebabkan oleh daun terpanjang yang diamati pada minggu sebelumnya mati dan atau disebabkan daun terpanjang yang diamati tidak selalu pada daun yang sama. Penelitian ini menghasilkan keragaan tanaman yang lebih baik daripada hasil penelitian Gatari dan Melati (2014) yang menggunakan polibag menunjukan bahwa tanaman tempuyung dengan penggunaan berbagai media tanam yang dicampur pupuk kandang sapi memiliki rata-rata panjang daun tertinggi $19.79 \mathrm{~cm}$, sedangkan rata-rata diameter tajuk terpanjang $36.20 \mathrm{~cm}$.

Tabel 1. Rata-rata tinggi tanaman tempuyung pada umur dan dosis pupuk yang berbeda

\begin{tabular}{|c|c|c|c|c|c|c|}
\hline \multirow{2}{*}{$\begin{array}{c}\text { Umur } \\
\text { Tanaman } \\
\text { (MST) }\end{array}$} & \multicolumn{5}{|c|}{ Dosis Pupuk Kandang Kambing (ton.ha ${ }^{-1}$ ) } & \multirow[b]{2}{*}{$\mathrm{KK}(\%)$} \\
\hline & 0 & 5 & 10 & 15 & 20 & \\
\hline & \multicolumn{6}{|c|}{. Tinggi Tanaman $(\mathrm{cm})^{\mathrm{tn}}$. } \\
\hline 1 & $1.27 \pm 0.20$ & $1.30 \pm 0.03$ & $1.19 \pm 0.06$ & $1.40 \pm 0.06$ & $1.25 \pm 0.06$ & 14.73 \\
\hline 2 & $1.68 \pm 0.15$ & $1.49 \pm 0.07$ & $1.51 \pm 0.10$ & $1.88 \pm 0.26$ & $1.54 \pm 0.11$ & 16.43 \\
\hline 3 & $1.95 \pm 0.09$ & $1.83 \pm 0.12$ & $1.92 \pm 0.05$ & $3.35 \pm 1.48$ & $1.94 \pm 0.11$ & $13.97^{\mathrm{t}}$ \\
\hline 4 & $2.36 \pm 0.16$ & $2.19 \pm 0.05$ & $2.21 \pm 0.06$ & $4.69 \pm 2.63$ & $2.37 \pm 0.32$ & $20.04^{t}$ \\
\hline 5 & $4.00 \pm 0.43$ & $3.53 \pm 0.31$ & $3.62 \pm 0.44$ & $7.11 \pm 3.74$ & $4.26 \pm 1.24$ & $19.05^{\mathrm{t}}$ \\
\hline 6 & $14.85 \pm 2.85$ & $9.90 \pm 0.79$ & $12.02 \pm 3.53$ & $20.39 \pm 9.14$ & $13.92 \pm 6.52$ & $20.34^{t}$ \\
\hline 7 & $37.43 \pm 10.63$ & $30.37 \pm 7.82$ & $29.71 \pm 9.51$ & $38.55 \pm 15.13$ & $41.14 \pm 14.86$ & 19.00 \\
\hline 8 & $69.98 \pm 11.08$ & $55.84 \pm 7.49$ & $61.38 \pm 12.14$ & $59.11 \pm 16.66$ & $64.49 \pm 15.05$ & 24.70 \\
\hline
\end{tabular}


J. Hort. Indonesia 5(3):148-157. Desember 2014.

Tabel 2. Rata-rata jumlah daun tanaman tempuyung pada umur dan dosis pupuk yang berbeda

\begin{tabular}{|c|c|c|c|c|c|c|}
\hline \multirow{2}{*}{$\begin{array}{c}\text { Umur } \\
\text { Tanaman } \\
(\mathrm{MST})\end{array}$} & \multicolumn{5}{|c|}{ Dosis Pupuk Kandang Kambing (ton.ha ${ }^{-1}$ ) } & \multirow{2}{*}{$\mathrm{KK}(\%)$} \\
\hline & 0 & 5 & 10 & 15 & 20 & \\
\hline & \multicolumn{5}{|c|}{............Tinggi Tanaman $(\mathrm{cm})^{\mathrm{tn}} \ldots \ldots \ldots \ldots$} & \\
\hline 1 & $4.4 \pm 0.3$ & $4.6 \pm 0.7$ & $4.5 \pm 0.5$ & $4.5 \pm 0.5$ & $4.4 \pm 0.4$ & 8.4 \\
\hline 2 & $5.6 \pm 0.3$ & $5.8 \pm 0.6$ & $5.5 \pm 0.4$ & $5.8 \pm 1.8$ & $5.5 \pm 0.5$ & 7.8 \\
\hline 3 & $7.4 \pm 0.5$ & $7.8 \pm 0.7$ & $7.5 \pm 0.6$ & $7.3 \pm 0.9$ & $7.4 \pm 0.8$ & 5.1 \\
\hline 4 & $10.1 \pm 0.6$ & $10.6 \pm 0.9$ & $10.3 \pm 0.8$ & $10.5 \pm 1.6$ & $10.5 \pm 1.3$ & 8.1 \\
\hline 5 & $17.5 \pm 2.3$ & $16.4 \pm 0.9$ & $16.2 \pm 1.7$ & $18.3 \pm 2.1$ & $19.2 \pm 4.0$ & 17.9 \\
\hline 6 & $25.0 \pm 3.5$ & $22.5 \pm 3.1$ & $21.2 \pm 1.6$ & $25.3 \pm 2.3$ & $27.1 \pm 3.8$ & 21.4 \\
\hline 7 & $33.8 \pm 5.1$ & $27.4 \pm 4.7$ & $29.4 \pm 1.8$ & $34.4 \pm 1.7$ & $39.0 \pm 6.1$ & 23.4 \\
\hline 8 & $43.2 \pm 6.2$ & $35.1 \pm 9.1$ & $37.0 \pm 3.9$ & $44.6 \pm 3.7$ & $48.3 \pm 6.4$ & 27.3 \\
\hline
\end{tabular}

Keterangan : \pm adalah standard error $(\mathrm{n}=3),{ }^{\text {tn }}$ menunjukkan hasil yang tidak berpengaruh nyata

Tabel 3. Rata-rata panjang dan lebar daun terpanjang serta diameter tajuk terbesar tanaman tempuyung pada umur dan dosis pupuk yang berbeda

\begin{tabular}{|c|c|c|c|c|c|c|}
\hline \multirow{2}{*}{$\begin{array}{c}\text { Umur } \\
\text { Tanaman } \\
\text { (MST) }\end{array}$} & \multicolumn{5}{|c|}{ Dosis Pupuk Kandang Kambing (ton.ha ${ }^{-1}$ ) } & \multirow{2}{*}{$\begin{array}{l}\mathrm{KK} \\
(\%)\end{array}$} \\
\hline & 0 & 5 & 10 & 15 & 20 & \\
\hline & \multicolumn{6}{|c|}{..Panjang Daun $(\mathrm{cm}) \operatorname{tn} . \ldots \ldots \ldots \ldots \ldots \ldots \ldots \ldots \ldots \ldots \ldots \ldots \ldots \ldots$} \\
\hline 1 & $13.53 \pm 1.47$ & $13.60 \pm 2.32$ & $14.44 \pm 1.89$ & $13.67 \pm 2.76$ & $14.04 \pm 1.91$ & 8.39 \\
\hline 2 & $14.47 \pm 1.09$ & $14.10 \pm 2.26$ & $14.86 \pm 1.78$ & $14.42 \pm 2.59$ & $14.28 \pm 1.59$ & 9.00 \\
\hline 3 & $17.80 \pm 1.10$ & $16.38 \pm 1.68$ & $17.04 \pm 1.15$ & $17.37 \pm 1.86$ & $17.32 \pm 1.76$ & 5.69 \\
\hline 4 & $23.26 \pm 1.05$ & $21.74 \pm 1.59$ & $22.30 \pm 1.10$ & $22.96 \pm 2.08$ & $23.28 \pm 1.86$ & 5.03 \\
\hline 5 & $25.01 \pm 0.89$ & $24.33 \pm 1.40$ & $30.97 \pm 7.52$ & $24.85 \pm 1.61$ & $26.19 \pm 1.90$ & 19.6 \\
\hline 6 & $27.32 \pm 1.18$ & $26.33 \pm 1.20$ & $26.10 \pm 1.10$ & $26.28 \pm 0.97$ & $28.33 \pm 1.36$ & 5.97 \\
\hline 7 & $30.25 \pm 0.74$ & $28.58 \pm 1.16$ & $28.11 \pm 1.08$ & $28.97 \pm 0.28$ & $30.54 \pm 1.39$ & 6.26 \\
\hline 8 & $30.53 \pm 1.05$ & $29.07 \pm 0.99$ & $29.19 \pm 0.86$ & $29.46 \pm 0.26$ & $30.53 \pm 0.92$ & 5.58 \\
\hline \multicolumn{7}{|c|}{ Lebar Daun $(\mathrm{cm}) \operatorname{tn} . \ldots \ldots \ldots \ldots \ldots \ldots$} \\
\hline 1 & $4.09 \pm 0.25$ & $3.69 \pm 0.32$ & $4.31 \pm 0.34$ & $4.16 \pm 0.55$ & $4.02 \pm 0.32$ & 5.52 \\
\hline 2 & $4.60 \pm 0.21$ & $4.12 \pm 0.26$ & $4.57 \pm 0.15$ & $4.64 \pm 0.38$ & $4.46 \pm 0.26$ & 4.52 \\
\hline 3 & $5.81 \pm 0.26$ & $5.33 \pm 0.27$ & $5.46 \pm 0.06$ & $5.61 \pm 0.39$ & $5.92 \pm 0.50$ & 6.33 \\
\hline 4 & $7.19 \pm 0.08$ & $6.71 \pm 0.28$ & $7.02 \pm 0.26$ & $7.06 \pm 0.20$ & $7.36 \pm 0.39$ & 6.13 \\
\hline 5 & $7.59 \pm 0.14$ & $7.17 \pm 0.14$ & $7.38 \pm 0.09$ & $7.38 \pm 0.03$ & $7.56 \pm 0.20$ & 3.21 \\
\hline 6 & $7.28 \pm 0.25$ & $7.16 \pm 0.31$ & $7.19 \pm 0.09$ & $7.37 \pm 0.20$ & $7.35 \pm 0.20$ & 5.61 \\
\hline 7 & $7.87 \pm 0.26$ & $7.17 \pm 0.34$ & $7.46 \pm 0.26$ & $7.37 \pm 0.08$ & $7.60 \pm 0.17$ & 5.96 \\
\hline 8 & $7.78 \pm 0.11$ & $7.35 \pm 0.34$ & $7.73 \pm 0.18$ & $7.36 \pm 0.08$ & $7.74 \pm 0.27$ & 5.45 \\
\hline \multicolumn{7}{|c|}{ 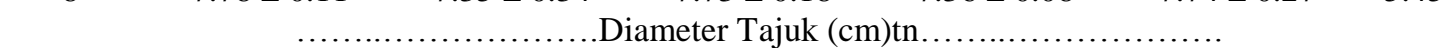 } \\
\hline 1 & $23.61 \pm 2.40$ & $23.66 \pm 3.98$ & $25.09 \pm 3.90$ & $24.28 \pm 5.73$ & $24.66 \pm 3.27$ & 9.75 \\
\hline 2 & $25.84 \pm 2.20$ & $25.26 \pm 4.05$ & $26.45 \pm 3.50$ & $26.67 \pm 5.48$ & $25.69 \pm 3.61$ & 8.98 \\
\hline 3 & $33.71 \pm 2.55$ & $30.93 \pm 3.20$ & $32.24 \pm 1.98$ & $32.62 \pm 3.93$ & $33.36 \pm 3.33$ & 6.55 \\
\hline 4 & $44.62 \pm 1.94$ & $41.49 \pm 2.94$ & $43.16 \pm 2.21$ & $44.01 \pm 4.07$ & $45.28 \pm 4.04$ & 5.53 \\
\hline 5 & $49.50 \pm 1.68$ & $47.83 \pm 2.56$ & $47.87 \pm 1.88$ & $49.06 \pm 3.07$ & $51.70 \pm 3.90$ & 5.93 \\
\hline 6 & $54.37 \pm 2.52$ & $51.82 \pm 2.37$ & $51.94 \pm 2.25$ & $52.58 \pm 1.82$ & $56.32 \pm 3.15$ & 6.57 \\
\hline 7 & $59.27 \pm 2.05$ & $55.90 \pm 2.56$ & $55.56 \pm 2.10$ & $56.92 \pm 0.41$ & $61.13 \pm 2.33$ & 6.42 \\
\hline 8 & $60.75 \pm 1.71$ & $57.86 \pm 2.68$ & $58.24 \pm 1.73$ & $58.89 \pm 0.38$ & $61.98 \pm 1.73$ & 5.82 \\
\hline
\end{tabular}

Secara umum tanaman tempuyung memiliki pertumbuhan yang baik selama 8 MST yang ditandai oleh penambahan nilai peubah vegetatif, bahkan ketika memasuki fase generatif penambahan nilai peubah vegetatif masih terjadi. Hal ini berbeda dengan hasil penelitian Gatari dan Melati (2014) yang me-nunjukkan penurunan nilai tengah peubah vegetatif ketika telah memasuki fase generatif, karena menurut Heldt (2005) ketika tanaman memasuki fase generatif, terdapat pemindahan penyimpanan fotosintat dari daun menjadi 
bunga atau buah. Akan tetapi, pada penelitian Wahyuningsih (2005) dengan dilakukannya pemangkasan bunga di awal pembungaan, jumlah daun tempuyung terus bertambah meskipun tanaman tempuyung sudah memasuki fase generatif.

\section{Pengaruh Dosis Pupuk Kandang Kambing terhadap Peubah Bobot Daun Segar dan Bobot Daun Kering Tanaman Tempuyung}

Pemberian pupuk kandang kambing dengan berbagai dosis tidak berpengaruh terhadap bobot daun segar dan bobot daun kering tanaman, walaupun saat tanaman berumur 8 MST bobot daun segar dan bobot kering daun mencapai nilai maksimal. Akan tetapi ketika 9 MST terjadi penurunan hasil hingga $78.52 \%$ dari hasil panen 8 MST (Gambar 1). Hal ini dikarenakan gejala serangan cendawan Puccinia sp. yang semakin tinggi, sehingga banyak tanaman yang busuk.
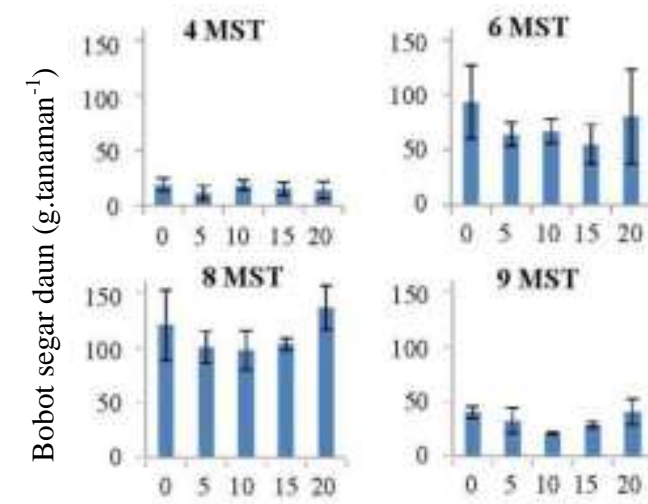

Dosis pupuk kandang (ton.ha ${ }^{-1}$ )

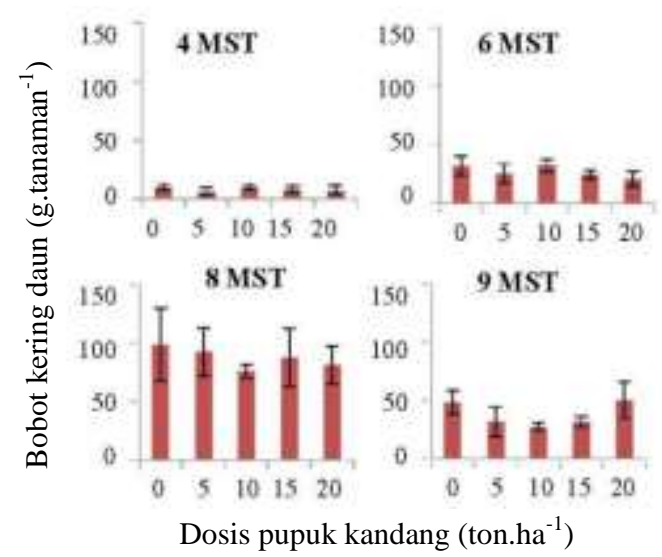

Gambar 1. Rata-rata biomassa daun total pada umur dan dosis pupuk yang berbeda, bar menunjukkan s.e., $n=3$, pengolahan data telah melalui ditransformasi $\sqrt{ }(\mathrm{x}+1)$
Tanaman tempuyung memiliki dua jenis daun yang dilihat berdasarkan umur dan letaknya, yaitu daun tua dan daun muda. Daun tua merupakan daun yang tumbuh sejak masa pembibitan dan letaknya dekat permukaan tanah, sedangkan daun muda merupakan daun yang mulai tumbuh pada 2 atau 3 MST dan letaknya di atas buku ke 4 batang serta percabangan. Apabila daun tua dan daun tua dibandingkan (Gambar 2), daun muda memiliki biomassa yang lebih tinggi daripada daun tua pada umur 8 MST, ini disebabkan oleh daun muda memiliki ukuran daun yang hampir sama dengan daun tua. Sesuai dengan Wahyuno (2012) cendawan Puccinia sp. banyak menyerang daun tua, sehingga banyak daun tua yang busuk.

Tinggi tanaman berkorelasi positif terhadap jumlah daun, hal ini menunjukkan bahwa semakin tinggi tanaman maka semakin banyak jumlah daun. Korelasi positif juga terdapat pada peubah jumlah daun dengan bobot segar daun, serta peubah bobot segar daun dengan bobot kering daun (Tabel 4).
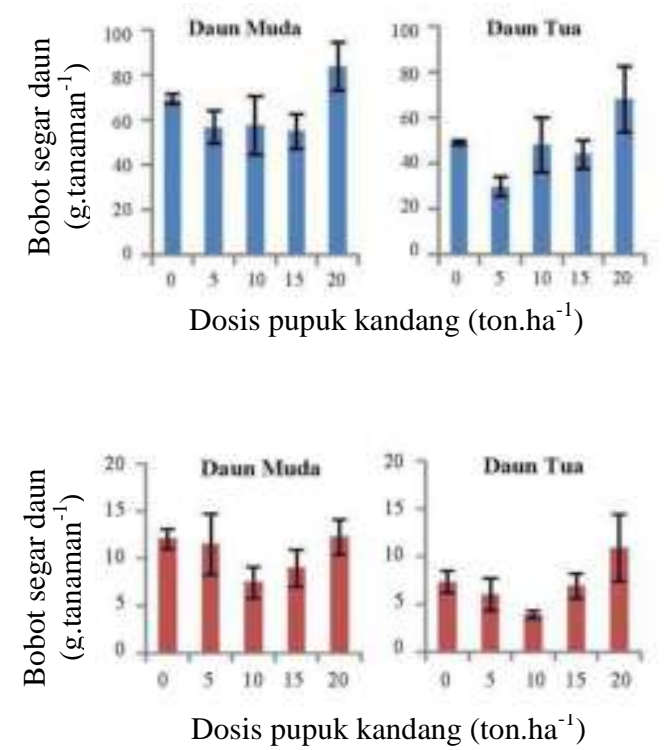

Gambar 2. Rata-rata biomassa daun 8 MST dengan dosis pupuk yang berbeda, bar menunjukkan s.e., $\mathrm{n}=3$

Bobot kering daun pada fase vegetatif (4 MST) berkisar antara 1.24 hingga $2.05 \mathrm{~g}$ $\operatorname{tanaman}^{-1}$, sedangkan pada fase generatif $(6$ MST) bobot kering daun mengalami peningkatan hingga $4.42 \mathrm{~g}$ tanaman $^{-1}$, bahkan pada 8 MST peningkatan bobot kering daun hingga $13.38 \mathrm{~g} \operatorname{tanaman}^{-1}$ (Gambar 2), serta 
produktivitas simplisia daun total pada 8 MST mencapai rata-rata $120 \mathrm{~kg} \mathrm{ha}^{-1}$. Hal ini menunjukkan produksi simplisia daun terus bertambah walaupun tanaman sudah memasuki fase generatif.

Tabel 4. Korelasi linear antara tinggi tanaman, jumlah daun dan biomassa daun pada 8 MST

\begin{tabular}{lcll}
\hline & $\begin{array}{c}\text { Tinggi } \\
\text { Tanaman }\end{array}$ & $\begin{array}{l}\text { Bobot } \\
\text { Segar } \\
\text { Daun }\end{array}$ & $\begin{array}{l}\text { Bobot } \\
\text { Kering } \\
\text { Daun }\end{array}$ \\
\hline Jumlah Daun & $0.681^{* *}$ & - & - \\
Bobot Segar & & & \\
Daun & 0.490 tn & $0.772 * *$ & - \\
Jumlah Daun & 0.240 tn & 0.499 tn & $0.649 * *$ \\
\hline
\end{tabular}

\section{Pengaruh Dosis Pupuk Kandang Kambing terhadap Peubah Kandungan Bioaktif dan Hara Tanaman Tempuyung}

Kandungan flavonoid total tertinggi yang terdapat dalam daun tempuyung adalah $11.67 \mathrm{mg}$ (g bobot kering) ${ }^{-1}$, sedangkan menurut Khan (2012) tempuyung memiliki kandungan flavonoid dapat mencapai 23.40 $\mathrm{mg}$ (g bobot kering) $)^{-1}$. Daun muda memiliki kandungan flavonoid yang lebih tinggi dibandingkan daun tua dengan selisih mecapai $8.18 \mathrm{mg}$ (g bobot kering) ${ }^{-1}$ (Gambar 3), diduga asimilat pada daun tua mengalami translokasi pada daun muda karena stress pada daun muda lebih besar daripada daun tua. Menurut Taiz (1991) kandungan metabolit sekunder dipengaruhi oleh cekaman lingkungan. Pemberian pupuk kandang kambing dengan berbagai dosis tidak memberikan pengaruh terhadap kadar flavonoid meskipun pada daun tua ada selisih yang lebih besar antara kadar flavonoid dengan pemupukan 20 ton $\mathrm{ha}^{-1}$ dengan tanpa pupuk.

Kandungan klorofil, karoten dan antosianin juga tidak dipengaruhi oleh pemberian pupuk kandang kambing, sehingga nilai peubah daun muda dan daun tua yang hampir sama untuk seluruh perlakuan dosis pupuk. (Gambar 3, 4 dan 5). Selain itu, adanya kandungan antosianin yang rendah menunjukan bahwa tingginya kandungan flavonoid total tidak didominasi oleh antosianin yang merupakan sub golongan flavonoid. Hasil ini sesuai dengan penelitian Khan (2012) menyebutkan bahwa kandungan flavonoid total pada tempuyung didominasi oleh orientin, quersetin dan kaempferol.
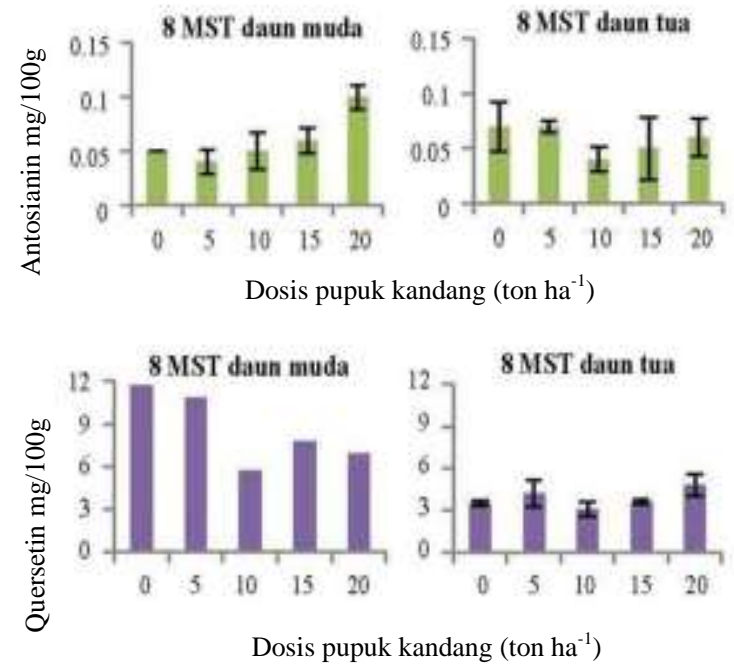

Gambar 3. Rata-rata kadar antosianin dan flavonoid total (dihitung sebagai quersetin) pada umur 8 MST dengan dosis pupuk yang berbeda (flavonoid daun muda diambil secara komposit, sehingga tidak ada analisis statistik), bar menunjukkan s.e., $\mathrm{n}=3$

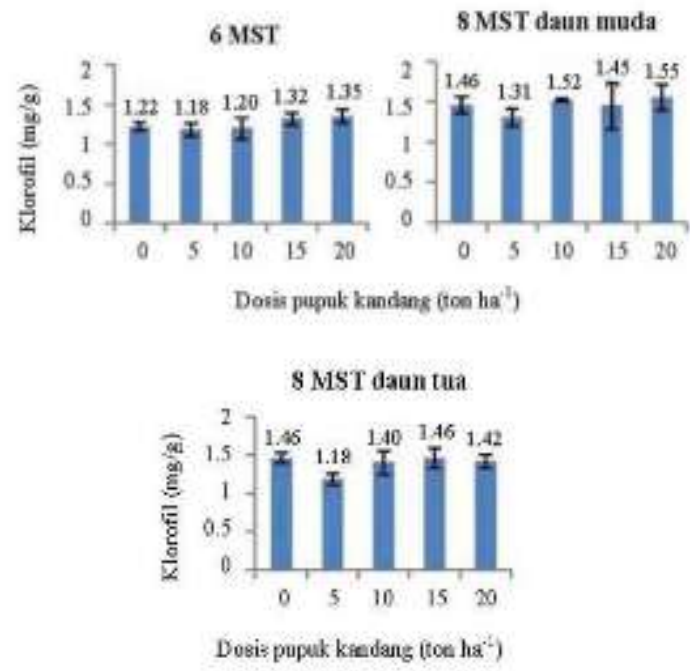

Gambar 4. Rata-rata kandungan klorofil pada umur dan dosis pupuk yang berbeda, bar menunjukkan s.e., $\mathrm{n}=3$ 


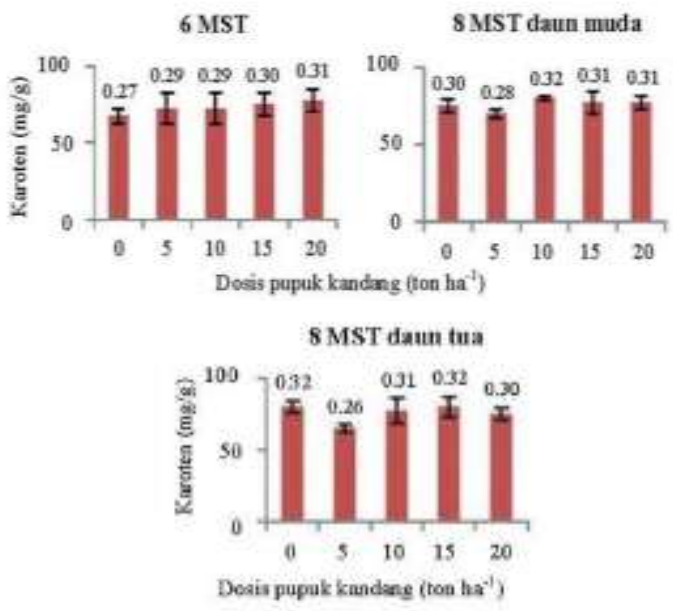

Gambar 5. Rata-rata kandungan karoten pada umur dan dosis pupuk yang berbeda, bar menunjukkan s.e., $\mathrm{n}=3$

Secara statistik, kadar nitrogen, fosfor dan kalium dalam tanaman tempuyung yang tidak dipengaruhi oleh pemberian pupuk kandang kambing, meskipun kadar fosfor dalam tanaman memiliki selisih yang tinggi antara tanaman yang dipupuk dengan dosis 10 ton $\mathrm{ha}^{-1}$ dengan tanpa pemupukan, dengan serapan fosfor mencapai $0.08 \mathrm{mg} \mathrm{g}^{-1}$. Begitu pula kadar kalium pada tanaman tempuyung yang dipupuk dengan dosis 20 ton ha ${ }^{-1}$ memiliki selisih yang tinggi daripada tanaman yang tidak dipupuk dengan serapan sebesar $0.42 \mathrm{mg} \mathrm{g}^{-1}$ (Gambar 6).

Ada kemiripan pola respon beberapa peubah bobot daun (Gambar 1) dengan kadar nitrogen daun (Gambar 6). Pemberian pupuk kandang kambing hingga 15 ton ha ${ }^{-1}$ justru menurunkan nilai peubah dan nilai peubah meningkat dengan pemberian dosis pupuk 20 ton ha ${ }^{-1}$. Penyebab kadar nitrogen yang rendah pada tanaman yang dipupuk dengan dosis hingga 15 ton $\mathrm{ha}^{-1}$ diduga karena pupuk kandang kambing yang digunakan belum terdekomposisi dengan baik, sehingga unsur hara $\mathrm{N}$ dalam tanah digunakan mikroba tanah untuk melakukan proses mineralisasi, dampaknya tanaman tempuyung tidak bisa menyerap hara (imobilisasi). Akan tetapi, pada tanaman yang dipupuk dengan dosis 20 ton $\mathrm{ha}^{-1}$ memiliki kadar N yang tinggi (Gambar 6) yang diduga karena kebutuhan hara bagi mikroba tanah berlebih, sehingga hara telah tersedia bagi tanaman. Menurut Paul dan Clark (1989) mineralisasi $\mathrm{N}$ organik merupakan proses imobilisasi $\mathrm{NH}_{4}{ }^{+}$dikarenakan $\mathrm{N}$ organik digunakan untuk pertumbuhan mikroorganisme dalam penguraian pupuk organik dalam tanah. Martajaya et al. (2010) menambahkan bahwa kesesuaian hara dipengaruhi oleh waktu antara ketersediaan hara dalam tanah dan kebutuhan tanaman akan unsur hara, apabila bahan organik yang diberikan dalam tanah belum terdekomposisi dengan baik maka perlu waktu dalam tanah agar hara dapat diserap tanaman.

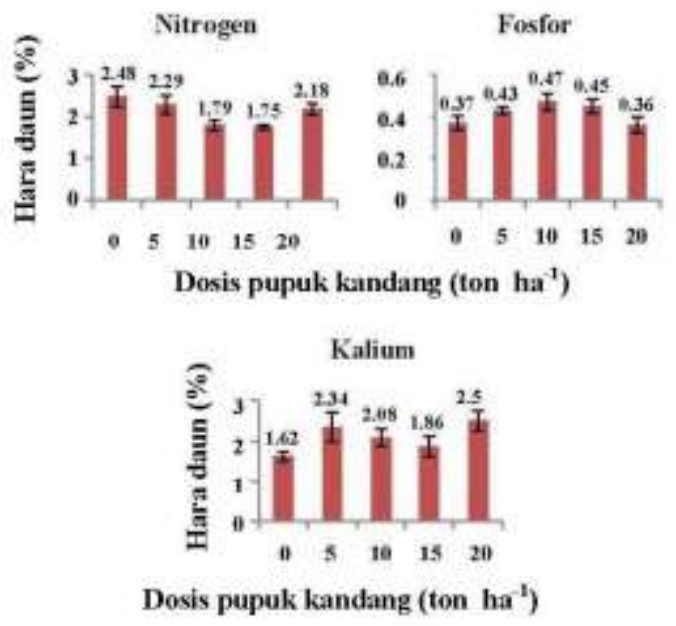

Gambar 6. Rata-rata kadar hara tanaman pada 8 MST dan dosis pupuk yang berbeda, bar menunjukkan s.e., $\mathrm{n}=3$

Tidak terdapatnya pengaruh dalam pemberian pupuk kandang kambing terhadap seluruh peubah yang diamati diduga karena kondisi iklim yang kurang sesuai (curah hujan dan kelembaban tinggi), sehingga berdampak pada tingginya serangan cendawan Puccinia sp. Dugaan lainnya adalah karena tanaman tempuyung merupakan tanaman yang adaptif tumbuh secara liar, sehingga dapat dibudidayakan meskipun tanpa dipupuk. Beberapa hasil penelitian menengenai pemupukan tanaman tanaman tempuyung menunjukan bahwa pemberian pupuk kandang sapi tidak berpengaruh terhadap produksi daun segar per tanaman (Januwati, 1993), penggunaan berbagai media tanam yang dicampur pupuk kandang sapi tidak mempengaruhi peubah vegetatif dan biomassa daun tempuyung (Gatari, 2014) serta pemberian pupuk NPK juga tidak memberikan pengaruh terhadap keragaan tanaman dan biomassa daun tempuyung karena dosis pupuk kandang yang diberikan sudah terlalu tinggi (Nurhayati et al., 2013). 


\section{KESIMPULAN}

Pemberian pupuk kandang kambing dengan berbagai dosis tidak mempengaruhi peubah vegetatif, biomassa, kandungan bioaktif serta kadar hara tanaman, walaupun pemberian pupuk kandang kambing menyebabkan pertumbuhan tanaman yang baik. Produktivitas optimal simplisia daun tempuyung terdapat pada 8 MST dengan nilai tengah mencapai 0.12 ton ha ${ }^{-1}$.

\section{DAFTAR PUSTAKA}

[BMKG] Badan Meteorologi Klimatologi dan Geofisika. 2014. Data iklim bulanan wilayah Darmaga Bogor. BMKG Bogor.

Burhanudin, Nurmansyah. 2010. Pemberian pupuk kandang dan kapur terhadap pertumbuhan dan produksi nilam pada tanah podsolik merah kuning. Bul.littro. 21(2): 138-144.

Baskoro, D., B.S. Purwoko. 2011. Pengaruh bahan perbanyakan tanaman dan jenis pupuk organic terhadap pertumbuhan tanaman Binahong (Andredera cordifolia (Ten) Stesnis). J. Hort. Indonesia. 2(1): 6-13.

Dalimartha, S. 2005. Tanaman Obat di Lingkungan Sekitar. Cet. 4. Puspa Swara. Jakarta.

Direktorat Budidaya dan Pascapanen Sayuran dan Tanaman Obat. 2009. Sosialisasi GAP dan Registrasi Lahan Usaha Tanaman Obat. http://ditsayur.Hortikultura.deptan.go.id/index.php?option= com_content\&view $=$ article $\&$ id $=123$ : reg-lu\&catid=34:berita-terbaru [8 Maret 2013]

Direktorat Jenderal Hortikultura. 2012. Keputusan Menteri Pertanian. http:// ditsayur.hortikultura.deptan.go.id/ index. php?option=comwrapper\&view $=$ wrapper \&Itemid=78. [9 maret 2013].

Gatari, D.D., M. Melati. 2014. Pertumbuhan dan produksi tanaman Tempuyung (Sonchus arvensis L.) dengan komposisi media tanam yang berbeda. J. Hort Indonesia. 5(1): 47-55.

Heldt, H.W. 2005. Plant Biochemistry. Ed ke3. Elsevier Science. hlm 339-345. California.

Hardjowigeno, S. 1989. Ilmu Tanah. Akademika Pressindo. hlm 128-129. Jakarta.

Hidayati. A, Yusrin, H. Anggraini. 2009. Pengaruh frekuensi penggunaan teh daun tempuyung (Sonchus arvensis L.) terhadap daya larut kalsium okasalat $\left(\mathrm{CaC}_{2} \mathrm{O}_{4}\right)$. Jurnal Kesehatan. 2(2): 30-37.

Izhar, L., A.D. Susila. 2010. Rekomendasi pemupukan fosfor dan potasium berdasarkan analisis hara tanah pada tanaman sayuran. J. Hort. Indonesia. 1(2): 81-88

Januwanti, M. 1993. Pengaruh jenis bibitdan pupuk kandang terhadap produksi daun tempuyung (Sonchus arvensis L.). Warta Tumbuhan Obat Indonesia. 2(3): 14-15.

Khan, R.A. 2012. Evaluation of flavonoids and diverse antioxidant activities of Sonchus arvensis. Chemistry Central Journal. 6(126): 1-7. doi: 10.1186/ 1752-153X6-126.

Martajaya, M., L. Agustina, Syekhfani. (2010). Metode budi daya organik jagung manis di Tlogomas, Malang. Jurnal Pembangunan dan Alam Lestari. 1(1): 1-8.

Nurhayati, H., I. Darwati, S.M.D. Rosita. 2013. Pengaruh pola tanam dan dosis pupuk NPK terhadap pertumbuhan dan produksi tanaman (Sonchus arvensis L.). Bul. Littro. 24(1): 8-13.

Paul, E.A., F.E. Clark. 1989. Soil Microbiology and Biochemistry. Academic Press. hlm 135-141. California.

Rohaeti, E., R. Heryanto, M. Rafi, Wahyuningum, L.K. Darusman. 2011. Prediksi kadar flavonoid total tempuyung (Sonchus arvensis L.) 
menggunakan kombinasi spektroskopi IR dengan regresi kuadrat terkecil parsial. Jurnal Kimia. 5(2): 101-108.

Sims, D.A., J.A. Gamon. 2002. Relationships between leaf pigment content and spectral reflectance across a wide range of species, leaf structures and developmental stages. Remote Sensing of Environment. 81(2):337-354. doi: 10.1016/S0034-4257(02)00010-X.

Sulasna, J., B. Santoso, D. Iskandar. 2004. Tempuyung: Budidaya dan Pemanfaatan untuk Obat. Penebar Swadaya. 115 hlm. Jakarta.

Taiz, L. 1991. Plant Physiology. Cummings Publishing. 565 hlm. California (US)

Wahyuningsih, A.P.S. 2005. Pengaruh kombinasi aplikasi pupuk $\mathrm{N}$ dan waktu pemangkasan tangkai bunga terhadap pertumbuhan dan produksi tanaman tempuyung (Sonchus arvensis L.) Skripsi. Program Studi Agronomi dan Hortikultura, Fakultas Pertanian, Institut Pertanian Bogor. Bogor.

Wahyuno, D. 2012. Temuan penyakit baru: Puccinia xantii penyebab bercak daun pada Xanthium sp. di Indonesia. Jurnal Fitopatologi Indonesia. 8(4): 116-119.

Winarti, C., N. Nurdjanah. 2005. Peluang rempah dan tanaman obat sebagai sumber pangan fungsional. Jurnal Litbang Pertanian. 24(2): 47-55.

Yuliarti, W. 2013. Isolasi, identifikasi dan uji antioksidan asam fenolat dalam daun tempuyung (Sonchus arvensis L.) dengan metode 1,1-difenil-2-pikrilhidrasil (DPPH). Chem Info Journal. 1(1): 294-304. doi: 10.3799/ sm.1.19.46. 